\title{
Android Application for Plants Identification Using Determination Key
}

\author{
Muhammad Arif Rifai \\ Department Biology Education, Faculty of Science \& Technology, Universitas Islam Negeri Sunan Kalijaga \\ J1. Marsda Adisucipto Yogyakarta 55281, Indonesia
}

\begin{abstract}
Rifai MA. 2017. Android Application for Plants Identification Using Determination Key. Proc Internat Conf Sci Engin 1: 215 218. This research aimed at producing application for plant identification using the Android-based determination key and determine the quality of the product application to use as a high school learning support. The study consisted of a preliminary study to identify and capture images of plants from 16 genera of 9 families pteridophyta and 206 genera of 82 families on Spermatophyta. The final result of the product in the form of master Android application with the extension *.APK. Aplikasi rated by one taxonomic expert, one media expert, one information technology expert, 5 peer reviewers, two biology teachers, and tested to 15 students of class X SMA. Overall assessment of the Android application identification of plants shows the percentage of $82.09 \%$ votes were included in the excellent qualifications, while the response of students get a percentage rating of $79.82 \%$ with good qualifications.
\end{abstract}

Keywords: Android, Identify plants, Key determination, App Inventor 2

\section{INTRODUCTION}

Classification of living things is one of the biology subject in high schools that contain many foreign terms (Latin). In this subject the students must understand the different rules in classification system of living things with scientific names of living beings. This subject requires a thorough understanding, so it need a learning media that can be repeated whenever and wherever students need it.

Plant identification is the process of determining the name/kind of plants specifically. The working principle of this plant identification is to compare or equate the characteristics of the plants that will be identified with other plants that have been identified. By the process of identifying the student will be easier to classify plants as well to know more detail of plant morphology.

There are several ways to identify plants, one of them is using determination key. Key determination is a tool created specifically to facilitate identification of plants. Key determination is made in classes, ordo, families, genera or species and so on. The characteristics of plants arranged so that the the key will select one among two or more properties to the contrary, and so on until finally obtained an answer, the identity of the plants.

Today, science and technology is develop very rapidly, especially the development of information and communication technology. The development of information technology encourage the various parties to create innovations in various fields. In the field of education there has been a lot of innovation that is created, one of which is the birth of the Electronic Learning (e-learning). Increasing number of people owning and using a mobile device open opportunities using mobile technology devices in education. The use of mobile devices in the learning process known as mobile learning (m-learning). The presence of $\mathrm{m}$ learning is intended as a complement to existing learning and provide opportunities for students to relearn material that is less controlled anywhere and anytime. This certainly can provide a different experience in the learning process for students.

One of the application development is the base operating system used in mobile phones. Android is an open source operating system that allows to develop application without licensing restrictions.

\section{MATERIALS AND METHODS}

This study is divided into three phases: identification and image capture plant, android application design, and testing the feasibility of the product

Identification and photographing study was conducted in the open green spaces in UIN Sunan Kalijaga, health clinic of veterinary of Gajah Mada University, the environment around Taman Satwa Taru Jurug, and the environment around the village Mambungan, Trasan, Juwiring, Klaten. Plants were identified to a genus level. Plants that have been identified then photographed as material for application development.

The design of software applications using App Inventor 2.

Assessment were carried out by taxonomic experts, one media expert lecturers, one expert on information technology (IT), 5 peer reviewers and 2 high school biology teacher. Limited trial conducted on 15 students of class X SMA. 


\section{RESULTS AND DISCUSSION}

In the first phase, we conducted research using plant identification keys from the book compiled by Dr. CGGJ Van Steenis. Furthermore, the results matched with the identification of other sources, and the Internet. The identification results subsequently corrected by experts to account for the validity. Based on the identification of plants from the green open spaces and locations that enabled diverse plant and easily found in everyday life, we got 16 genera of 9 families in sub division pteridophyta and 206 genera of 82 families of plants Spermatophyta.

We targeted a plant that is often encountered in everyday life because the application is projected for the introduction level and is not intended to identify a new or rare one.

Picture/photo selected as one of the components in the application because it has many advantages, including: (1) Real object. Photograph can be viewed by learners more clearly and realistically, (2) safe space and time. To demonstrate the plant species/species that do not exist in Indonesia, (3) minimizing the limitations of the eye observation. to explain certain objects that difficult to direct observation, we used drawings or photographs (4) cheap and easy (Jatmika, 2005). With these advantages the image/ picture is suitable for use as one component in a particular application to indicate the genus of plants.

File picture/photo memory requires a relatively large when compared with text files. Therefore each genus is represented only by 1-3 images related to the special characteristics of their morphology. Pictures/photos of plants that have been processed using Corel Draw X6 and Windows Picture Manager. Windows Picture Manager is used to reduce the capacity of the storage size. Corel Draw X6 is used to compose images into a single extension * .JPG image files thus becomes quick and simplify design of android application at a later stage.

The second phase of the research is the design of android applications using App Inventor software developers 2. App Inventor 2 is an online software application development of android. This software was created by MIT Scheller Teacher Education Program that is taken from research by Ricarose Roque. Software App Inventor 2 allows new users to create software applications for the Android operating system. App Inventor 2 uses a graphical interface, which allows users to drag-and-drop visual objects to create applications that can run on android devices (Hendrik et al, 2015).

In the process of designing the plant identification application, developers must consider several aspects. The first aspect is that the resulting applications will run on mobile devices with limited hardware. The images used in applications created with a size as small as possible, but also not leave the essence of the image. Thus the application size is not too big so they can be used on the phone with low specifications. The sentence contained in the application are made as short as possible, especially in the identification menu. It is intended that it is easy in the use of identification. According to Muhammad (2011) simplicity is an important point in the development of applications, because basically people do not like something complicated because it will make human beings tend to get bored.

Menu applications compiled with the shape of the tree. At each supplied User Interface "back" button. and use your "back" button on the phone leads to the app's main menu. Thus all use processes based on the main screen. Background applications, images, icons, and the layout is made such that the display media become attractive by promoting simplicity and identity applications. This is because the use of colors that are too complex element would create too heavy when the application is run, and reduce application luxuries.

The assessment aims to determine the feasibility of the product. In addition, the reviewer also give input and suggestions are used by developers to make improvements to the products developed.Assessment of quality of products made by experts, are subject matter experts and media experts are presented in Table 1.

Table 1. Assessment of applications by experts.

\begin{tabular}{lllll}
\hline No. & Aspect & Max score & The average score & Percentage Value $(\boldsymbol{\%})$ \\
\hline 1 & Matter & 90 & 82 & 91.11 \\
2 & Language & 25 & 21 & 84 \\
3 & display & 90 & 69 & 76.6 \\
4 & Software engineering & 25 & 22 & 88 \\
5 & implementation & 15 & 15 & 100 \\
6 & interface & 20 & 10 & 50 \\
7 & reusable & 5 & 4 & 80 \\
8 & Compatibility & 10 & 7 & 70 \\
9 & maintainability & 10 & 8 & 80 \\
& Total & $\mathbf{2 9 0}$ & $\mathbf{2 3 8}$ & $\mathbf{8 2 . 0 7}$ \\
\hline
\end{tabular}

Based on assessments by media experts, subject matter experts and information technology specialists resulted in a percentage value of $82.02 \%$. The results of product assessment by five peer reviewers are presented in Table 2. 
Table 2. Assessment by peer.

\begin{tabular}{lllll}
\hline No. & Aspect & Max score & The average score & Percentage Value $(\boldsymbol{\%})$ \\
\hline 1 & Matter & 50 & 42.8 & 85.6 \\
2 & Language & 25 & 20.8 & 83.2 \\
3 & display & 55 & 48.4 & 88 \\
4 & Software engineering & 15 & 13.6 & 90.6 \\
5 & implementation & 10 & 9.2 & 92 \\
& Total & $\mathbf{1 5 5}$ & $\mathbf{1 3 4 . 8}$ & $\mathbf{8 6 . 9 7}$ \\
\hline
\end{tabular}

Based on the assessment by peer reviewers all aspects of obtaining an average percentage of $86.97 \%$ value that indicates the quality of applications in the category of Very Good (SB). The results of product assessment conducted by teachers of biology are presented in Table 3.

Table 3. Assessment by a biology teacher.

\begin{tabular}{lllll}
\hline No. & Aspect & Max score & The average score & Percentage Value $(\%)$ \\
\hline 1 & Matter & 50 & 38 & 76 \\
2 & Language & 25 & 20.5 & 82 \\
3 & display & 55 & 43.5 & 79 \\
4 & Software engineering & 10 & 7.5 & 75 \\
5 & implementation & 20 & 17 & 85 \\
& Total & $\mathbf{1 6 0}$ & $\mathbf{1 2 6 . 5}$ & $\mathbf{7 9 . 0 6}$ \\
\hline
\end{tabular}

Assessment by the biology teacher to plant identification applications shows that the applications developed have qualities Good (B) with a percentage value of $79.06 \%$.

The overall assessment of applications identification of plants by one media expert, one expert material, one information technology experts, 5 peer reviewers, and two biology teachers from the aspects of display quality, materials, software engineering, linguistics, enforceability, interface, reusable, maintainable, and combatibility presented in table 4 as follows:

Table 4. Rate all the reviewer in every aspect.

\begin{tabular}{llll}
\hline No. & Aspect & Percentage Value (\%) & Quality \\
\hline 1 & Matter & 85.63 & Very Good (SB) \\
2 & Language & 82.67 & Very Good (SB) \\
3 & display & 79.20 & Good (B) \\
4 & Software engineering & 86.20 & Very Good (SB) \\
5 & implementation & 89.29 & Very Good (SB) \\
6 & interface & 50.00 & Enough (C) \\
7 & reusable & 80.00 & Very Good (SB) \\
8 & Compatibility & 70.00 & Good (B) \\
9 & maintainability & 80.00 & Very Good (SB) \\
& Total & $\mathbf{8 2 . 0 9}$ & Very Good (SB) \\
\hline
\end{tabular}

The total yield assessment by all reviewers of all aspects of the percentage gain in value by $82.09 \%$, so that the plant product identification applications included in the category of Very Good (SB).

Android apps using the plant identification determination key results of further development to the students tested. The purpose of the product is tested to determine the extent of the effectiveness of plant identification android application development results in terms of cognitive, psychomotor and affective. Product test performed in Madrasah Aliyah Negeri 1 Surakarta. Based on the test results of the product, the value of the response from the students presented in Table 5. 
Table 5. Student response to the application.

\begin{tabular}{lllll}
\hline No. & Aspect & Max score & The average score & Percentage Value (\%) \\
\hline 1 & Retention of material & 25 & 21.3 & 85.2 \\
2 & display & 50 & 37.1 & 74.2 \\
3 & linguistic & 15 & 12.1 & 80.6 \\
4 & implementation & 25 & 21.3 & 85.2 \\
& Total & $\mathbf{1 1 5}$ & $\mathbf{9 1 . 8}$ & $\mathbf{7 9 . 8}$ \\
\hline
\end{tabular}

Students' response to plant identification applications covering aspects of understanding, views, language, and enforceability. The average yield of the overall aspect of obtaining a percentage value of $79.82 \%$ that indicates an application has good quality (B).

The existence android smartphone operating system among people have diverse uses, according to a survey conducted by Google in collaboration with TNS Australia (Kompas, 2016) found that Android users in Indonesia is dominated by social media activity in the first rank and chat rated second. In third place, the Indonesia-dominated activity "gugling". Other activities that online shopping and entertainment search. Despite the usefulness of android, it is dominated by the communication but not a few users who use android as a means to find information and learn by using applications available on the app market. Thus the development of mobile learning must always be upgraded to support education for learning more varied even a challenge to make mobile learning into one of the priority objectives someone uses android smartphone operating system. According Sastroprawiro (2011) Indonesia needs to introduce and implement the concept of education revolves diverse activities, varied programs to create a good academic atmosphere.

Identifying the plants required careful observation of the morphological features of the object (Cullen, 2006). Indeed plant identification can be done in several ways, one using the key determination. Key determination is a tool created specifically to facilitate the plant identification.

\section{CONCLUSIONS}

Based on the research that has been done, we can obtain some conclusions as follows: (1) identification of plants to developed Android applications through the identification stage and plants image capture, data entry into software developers, preparation of layout and provision of activities on the application. The final result are the product in the form of master Android application with the extension * .apk. (2) The quality of plant-based identification applications android based on the overall reviewer consisting of experts, peer reviewers, and biology teachers earn a percentage value of $82.09 \%$ which is included in the qualification very well be used as a medium of learning. Students' response to the identification of plant-based android application shows that plant identification applications gain $79.82 \%$ percentage value that is included in the qualification both be used as a learning media.

\section{REFERENCES}

Atwi, Supaman. 1997. Design Intruksional. Jakarta: The Open University

Cullen, James. 2006. Practical Plant Identification. Cambridge University

Hendrik, Billy; Mardhiah Masril; Alexyusandria Moenir. 2015. Utilization of Mit App Inventor 2 In Building Control Application Round Speed Electric Motors. Journal of Information Technology vol 8-2

Jatmika, Herka Maya. 2005. Utilization of Visual Media in Supporting Learning in Primary School Physical Education. Indonesian Journal of Physical Education, vol 3-1

Kadir A.; LE Nugroho; A. Susanto; PI Santosa. 2011. Neural Network Application on Foliage Plant Identification. International Journal of Computer Applications. Vol 29-9

Mahendra, I Gede Jaka. 2011. Based Learning Media Development Blog On Subjects nformation and Communication Technology Class Vi Smp Negeri 1 Sukasada. www.pasca.undiksha.ac.id accessed on 5 October 2014 at 19:02

Mangold, Jane. Identification 2013.Plant Basics. Montana: Montana State University

Muhammad, Al. 2011. Designing Interactive Map Travel Supporting Location-Based Multimedia Tanjungpinang.

Purbasari, Rohmi Julia; M. Shohibul Kahfi; Mahmuddin Yunus. 2013. Android Application Development For Media Learning Mathematics In Three Dimensions Material For Class X Student Exp. Malang: The Negeri Malang University

Randler, Christoph .2008. Teaching Species Identification - A prerequisite for Learning Understanding Biodiversity and Ecology. Eurasia Journal of Mathematics, Science \& Technology Education. Vol 3, 223-231

Sastroprawiro, WN (2011). The Missing Abundance Mentality in Our Curriculum in Student Thought Series: Indonesian Economy in the Eyes of Young Children UI. UI: Baduose Media

Watson S \& T Miller .2009. Classification and the dichotomus key teaching tools for identification (report). Article The Science Teacher: 5054 